\title{
Effect of Physical Changes on the Spatial Structure of Historical Area, the Historical District of Urmia City as a Case Study
}

\author{
Yasin Lotfata ${ }^{1} \&$ Aynaz Lotfata $^{2}$ \\ ${ }^{1}$ Architecture Faculty, Middle East Technical University, Ankara, Turkey \\ ${ }^{2}$ Geosciences Department, Mississippi State University, Starkville, USA \\ Correspondence: Aynaz Lotfata, NSPARC, 600 Russell St. Starkville, MS., 39759, USA. Tel: 1-662-994-0820. \\ E-mail: al1957@msstate.edu
}

$\begin{array}{lrr}\text { Received: May 23, } 2018 & \text { Accepted: June 22, } 2018 \quad \text { Online Published: July 29, } 2018 \\ \text { doi:10.5539/jsd.v11n4p174 } & \text { URL: https://doi.org/10.5539/jsd.v11n4p174 }\end{array}$

\begin{abstract}
Recently, urbanism interventions have caused major changes in the spatial and physical structure of Iran cities. These interventions have changed primary spatial organization pattern and the city's main structure. In the process of this physical development in many historical cities, it has not been enough attention to the structure and historic core shape of the city and subsequently, problems such as the inability to adapt to the new physical changes, the lack of appropriate linkage with the available network structure and its diminution in the minds of people, have aggravated the historical cores. Recognition of the main cities structure and skeleton based on analysis of all components of cities is difficult and impossible. Space organization theory (space syntax) is one of the methods that has responded to the needs of cities' spatial analysis.

This research, with the aim of investigating the impact of urban development plans on the spatial structure of the historical boundaries of Urmia investigating and analyzing the city structure in four important periods (2016-1996-1974-1930), using space organization method. Results of this study, demonstrated that was decreased functionality and coherence of the historical area and its relation to the totality of city structure affected by physical changes over time. And the inner structure of this area could not be linked to the city's overall structure. Also, a large part of the identity and physical values of texture are demolished by discontinuity of the main elements of the area. The functional importance of historical orders has been weakened and this means that rapid physical changes, had negative effects on the spatial structure of historical area.
\end{abstract}

Keywords: physical transformation, spatial organization, urban space, historical development, Urmia, Iran

\section{Introduction}

With new developments in urbanization, the ancient and historical parts of big cities are exposed to undesirable effects of urban development more than other urban areas. This phenomenon has appeared in various forms in the all of Europe, Asian ancient cities and countries with a long history of urbanization. Therefore, the importance and necessity of preserving the old texture, has always been considered, not as symbolic phenomena, but because of revealing the evolution and development of urbanization history and civilization, identity and historicity preservation (Ahmadifar, 2006). In the process of physical development in many Iran's historical cities, are not sufficient attention to the structure and form of the historical core and has created problems such as the inability to adapt to new physical changes, lack of proper linkage with available network structure and spatial isolation of historical cores. Actually, ignoring the physical and non-physical values of available context and implementing hasty plans has led to the decline of these historical cores in the people's mind. The characteristic of many of our historic cities is that they are subjected to external development forces, either transformed into non-habitation parts or are buried in new structure (Lotfata, 2015).

In the past decades, Urmia city, center of West Azarbaijan province has been observed wide changes in the structure of texture and the traditional skeleton and the historical core of this city, like many other cities in Iran, has undergone many problems due to the hasty developments taken by industrial development and modernism. This research is aimed at revealing and analyzing the process of Urmia urban development and urban extension of Urmia in the last few decades and structural analysis and spatial configuration, during different periods. This study seeks to assess and evaluate the changes in the value and function of historical texture and important 
historical orders and to be effective to solve the structural-physical problems of this historic and valuable area, by accurate recognition of the spatial structure and connections and spatial coordination (Lotfata and Lotfata, 2018).

\section{Research Methodology}

In the first stage of this research, physical changes and spatial structure of the historical core of the city is being studied by using Space Syntax method and its purpose is to study Urmia city development and its physical-spatial structure changes, has been used of descriptive and historical research method. The framework and theoretical foundations of research have been compiled and presented accordingly. The information and data required at this stage are prepared in two ways: a) Documentary: by using historical documents, and the study of Urmia urban development plans, such as comprehensive and detailed plans. b) Field observations. In the next stage, based on the information gathered will be paid to analyze of the city development process and explaining the factors affecting the changes in Urmia city physical - space structure.

\section{Theoretical Foundations}

\subsection{Urban Spatial Structure}

Cole Cohen (1989) defines the urban space term in two ways: the social space and created and artifact space. The social space is the spatial association of social institutions which is of interest to sociologists and urban geography. This viewpoint considers the features of the artifact environment as an over-phenomenon and the other hand, the artificial space is about the physical space which is of great interest to architects (Madanipour, 1996).

Urban spaces in the sense of a scene in which public activities of urban life take place. The streets, squares, and parks of a city form the city's activities. These dynamic spaces, in contrast to the fixed and non-motionless space of living and working, constitute the main and vital components of a city and provide the network of communication centers and public spaces and recreation in the city (Bahraini, 2009).

Here it is necessary to reminding a gestalt approach in psychology that implies it's impossible to reduce the whole to its components and the whole has a separate behavior from its components and in fact, that which forms the behavior and position of the components is the whole properties (Ganbari, 2008).

The metabolists, who were a group of Japanese structuralists architects and urban planners, they said there are two phenomena in the mechanism of change: Elements with short life and enduring elements. Indeed, main section and non-main section. According to their beliefs, two issues appear in the mechanism of the transformation of cities: first, the city's substructures (like body skeletons) which have a long-life span (Lotfata, 2013). Second, neighborhoods, blocks of houses and arteries used for daily activities (such as tissues and body cells). This group of elements have less longevity unlike the first group and they are capable of revising and changing and in a continuous process, separated from the main structure, disappear and rebuilt again (Pakzad, 2006). Actually, these enduring elements are structure of same city that is described in view of metabolites well. The construction of each city on the one hand represents the coordination of city's physical spaces with conditions and factors mentioned and the other hand is an indication of how the proceeding of city's main activities (Lotfata and Sadeghi, 2009). Of course, the main structure of city is a connected and interconnected set of urban spaces (including street and square) which contains the main elements and basic activities of the city (Dolati, 2013). 
Table 1. Basic views in spatial structure

\begin{tabular}{ll}
\hline Row Viewpoint & Description \\
\hline & Based on this view, the city operates as a system that includes a set of \\
& numberless of sub-systems that have a different impact and in general \\
& create a complex set. Thus, the construction of a large city specifies the \\
& part of city systemically system that that provides a flexible framework \\
& for the formation of various subsystems during growth \\
& periods(Pakdaman, 1993). \\
\hline \multirow{3}{*}{ Constructivism } & The constructivists believe that, along with performance, construction of \\
& spaces should also be considered. From their point of view, the principle \\
& of relation is one of the important principles that builds the spaces. By \\
& building the city spaces, it is possible to form communication activities \\
& and flows that take place within space. Therefore, it can be concluded that \\
& constructivism in urban scale, location and spatial organization, \\
& construction, communication and other components of the city shape \\
& takes into account (Bazrgar, 2003). \\
\hline Some sociologists consider the spatial structure of city to be effective in \\
human relationships. Here are some comments from some of them. In \\
George Simmel's view, there is a reciprocal relationship between the \\
pattern of spatial arrangement and social processes. Durkheim considers \\
the concentration and concentration of communities and the resulting \\
spatial forms as a disability in social relations, which in turn requires a \\
significant impact on social and economic relations simultaneously in the \\
emergence of an urban community (Weber, 1990).
\end{tabular}

\subsection{Relationship between City Form and City Structure}

Understanding the concepts of city shape and city structure, explained close and bilateral relation between them. If we consider the shape of city as a set of physical, natural, activity, including the element of time, it can be said that among this set, Indicator and unchangeable elements form Structure of city (Figure 1). 

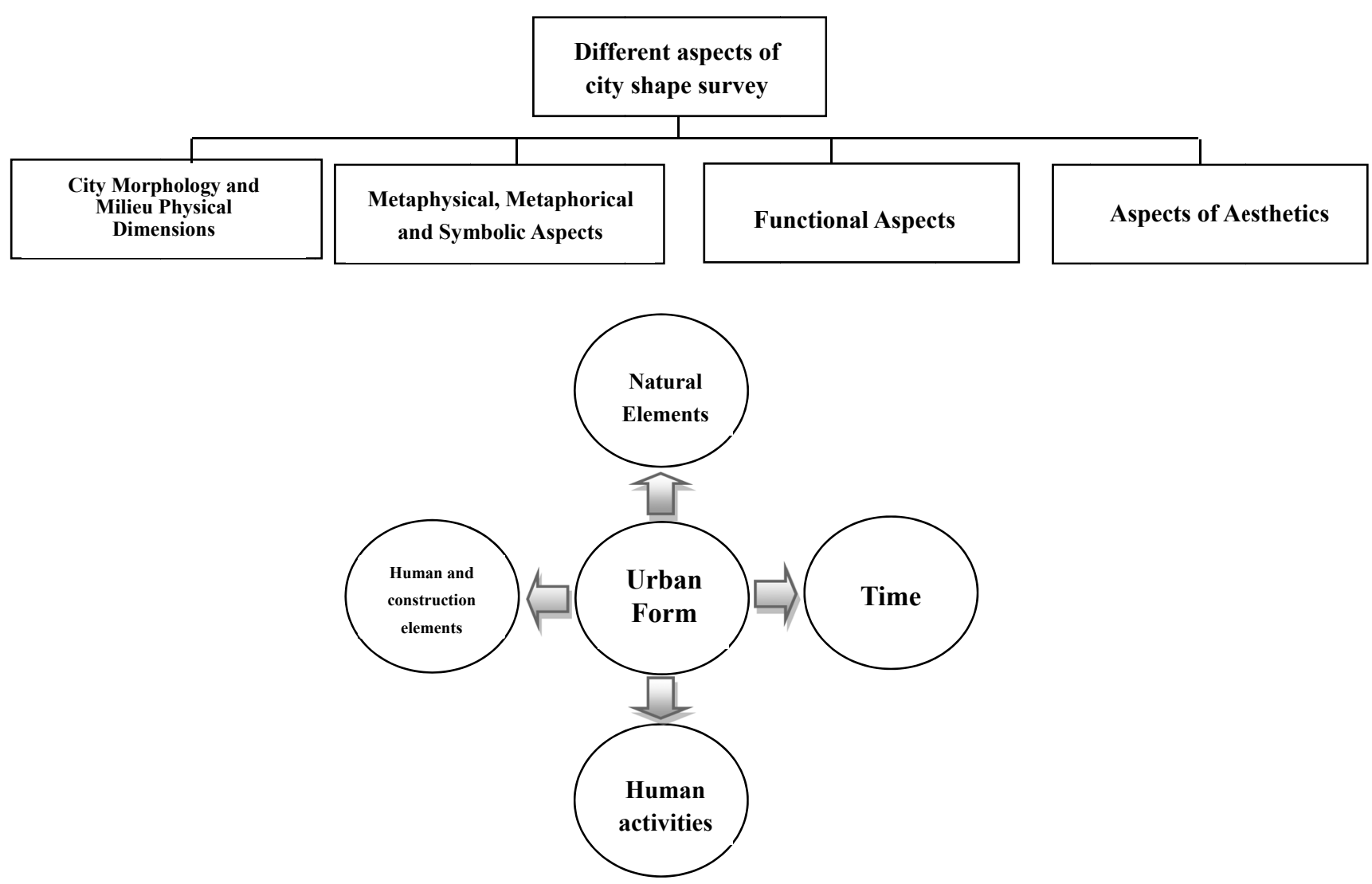

Figure 1. Different approaches to investigate the city form and the main components of urban form

\subsection{Factors Affecting the Transformations of City Physical-spatial Structure}

Cities are constantly growing and developing, and this transformation also occurs in the nature of the elements, spatial order and spatial organization of them (Zekavat, 2011). Ziari (2013) believes that the spatial structure of cities depends on the different and reciprocal relationships of all forces and city factors. These factors can include market forces, activities, urban infrastructure, and various services that have always had a complex and reciprocal relationship (Ziari, 1999). Table 2 shows the list of general urban processes affecting the changes of physical-spatial and urban form on time scale. Gradual processes relate to technical-economic paradigms, including structural changes in the global economy, demographic changes, and the introduction of new technologies (Ambinakudige et al., 2017). Fast processes involve the communications flow (which can happen in the digital world in any moment) and daily cycles of urban travel. The processes affecting the spatial structure of cities in terms of lands use and urban performance are considered to be medium in terms of time, including location of factories, commercial centers and residential areas. These processes, in turn, depend on both a dynamic and faster process (such as travel patterns that affecting access) and a slower process (such as economic change that affects the dominant forms of economic production in different urban periods) (Madanipour, 1996). The city's spatial structure is the result of historical processes and changing economic, social and political conditions, as well as natural-environmental factors, which are discussed in more detail below. 
Table 2. Urban change

\begin{tabular}{lll}
\hline \multicolumn{1}{c}{$\begin{array}{c}\text { Slow Processes } \\
\text { (Over Decades or Centuries) }\end{array}$} & \multicolumn{1}{c}{$\begin{array}{c}\text { Medium Processes } \\
\text { (Less than 10 Years) }\end{array}$} & \multicolumn{1}{c}{$\begin{array}{c}\text { Fast Processes } \\
\text { (Daily or Faster) }\end{array}$} \\
\hline -The structural changes in the & -Location of factories and industries, & -Communication flows (very \\
global economy & residential lands and ... & fast electronics) \\
-Major demographic changes & -Urban development cycles & - Travel patterns \\
-Changing the technical-economic \\
paradigm
\end{tabular}

\subsection{Study of Physical Development and the Process of Historical Formation of City}

By examining the characteristics of physical development and the process of historical formation of Urmia in different periods, we can deduce the following:

1) The ancient city of Urmia, with an area of nearly 300 hectares before the beginning of 1921s, was a coherent and integrated totality which was defined by peripheral rampart and the only ways to connect it outside were from the city's seventh gates. This totality and its functional and physical structure, by the time of 1921 - during the different periods - has the identical and irreplaceability characteristics.

2) The establishment of Urmia on important commercial routes as well as borderline position and the favorable climate and natural resources has always provided the necessary means for the development of civilization and the prosperity of urban life and the only deterrent to urban development in the pre-1921, attacks by neighboring countries, and religious and ethnic conflicts in the city.

3) The Urmia city, was slowly growing until the late Qajar dynasty in Iran. Urmia has mainly agricultural relations. But since 1921, due to Reza Khan's involvement in the cities, has undergone fundamental changes in its structure and function. Since then, due to physical development increased migration to the cities and its changes were fast.

4) The main factor influencing the development of city in the last century before 1978, including streets, creating the present physical and functional environment in cities as well as land reform and the immigration phenomenon. But after the victory of the Islamic Revolution, immigration to cities such as Urmia was intensified due to insecurity in cities and especially in the cities and villages of southern and western borders in the country (due to occurrence of imposed war) and its effect became more prominent than other factors. As almost half of the migrant population arrived in Urmia in the late 1990s.

5) In the last two decades, the main factors in the city development, roads development and housing developments around them, and to a lesser extent, have been the phenomenon of migration which has led to the annexation of peripheral lands to the city, cooperative settlements, development and the creation of disadvantaged and marginalized settlements.

6) In recent years, in order to respond to the problems caused by the city's horizontal development, as well as to respond to the increase in population and the need for housing, the policy of increasing congestion, especially through vertical development, has been on the agenda.

7) Not creating of residential units in partitioned lands - especially in the lands of cooperatives and government departments - shows that these measures have not been in actual needs of the city, and the economic issues of land and housing have been affected in this regard.

\subsection{Space Organization Theory in the Analysis of Structure and Spatial Organization of Cities}

With the sudden growth of population in the last century and consequently, the dispersed and unsettled development of cities, it has changed the pattern of the spatial organization of city and its main structure. On the other hand, increasing the extent of cities has caused the physical-spatial complexities in cities. It is difficult and impossible to understand urban relations and recognize the main structure and skeleton of cities and its morphology based on analysis of all city's components (Lotfata and Sadeghi, 2009). Therefore, spatial structure analysis of cities requires methods that can respond to these complexities. Among the theories and methods that study the structure and configuration of urban space, is the space organization theory (Hillier, 2007). If we look at the urban space, just from its physical aspect, we have in fact considered the physical space of city. Therefore, the physical space of an urban system is a three-dimensional building (Euclidean geometry). The phenomena 
within it can be considered in terms of concepts such as point (retail, school, hospital), line (communication lines), and surface (land, neighborhood parish, area) and volume (buildings) (Harvey, 2000). Lefebvre (1991) defines the social space as follows:

"Social space is a social product. Each society and the mode of production are producer of its own space (Lotfata,2013). Consequently, the concept of space production is shaped which plays a key role in Lefebvre's thinking. Space is trade like a product, as a social and political product. Therefore, the environment and society organization, as well as patterns of cities and regions, all depend on the space of production and its role in reproducing the social-economic formation" (Madanipour, 1996). Harvey also states that it is safe to say that physical construction should facilitate the coherent revenue of the social process. But space is not completely compatible with this process. On the other hand, social needs are not compatible with any form of space (Harvey, 2000). Therefore, paying attention to the social dimension of space, can help us to create successful urban spaces like accentuate to the spatial structure.

\section{The Emergence and Development of Urmia City's Surface and Demographic Changes in Modern Times} (1921 - 2011)

Resident population of Urmia has grown on average over the past few decades and has increased from 67.6 thousand in 1956 to approximately 6,577 thousand people in 2011 and has been more than 10-fold during these six decades. In order to find out how to expand the city, it is necessary to examine the population growth process as well as the extension of its area of physical range. Hence, it has been considered how to change of population and city area from 1921 - 2011(Table 3).

Table 3. Survey of surface and demographic changes of Urmia from 1921 - 2011 (Statistical Center of Iran, 2011 and Design and Planning Consultant Engineers, 2009)

\begin{tabular}{rccccccccc}
\hline 2011 & 2006 & 1996 & 1986 & 1976 & 1966 & 1956 & 1951 & Description \\
\hline 677499 & 583255 & 435200 & 300746 & 164419 & 110749 & 67605 & 20000 & $\begin{array}{c}\text { Urmia City Population } \\
2.01\end{array}$ \\
& & 3.3 & 3.76 & 6.22 & 4.03 & 5.06 & - & Average annual urban population growth \\
(percent)
\end{tabular}

\subsection{Initial Core of City}

It is certain that cannot be provided a exact date for the formation of residence place for this place. But according to historical documents and archaeological evidence, the antiquity of this settlement center (city) back to the first millennium BC. For the first time, it has been talked about fortress named "Armate" (Oramiyat), documented and codified, in Assyrian resources (first millennium BC) which, according to some historians, it has been in the present position of Urmia city. (Rismanchian et al., 2013).

There is no available information about the existence history of Urmia city in the 2nd millennium BC, but signs of a housing center have been obtained in current hill and plain of Urmia city, dating to the first millennium BC. Also, during the historical researches and discoveries that is accomplished in the area of Urmia, were identified three sets of man-made collections that they were gathered with a distance around the main range. Accordingly, the settlements of the Aryan, Median and Achaemenid tribes, which were located in three periods and at different intervals from a primary core have been considered as the main factors of primary development of city's core.

A range of $4 \mathrm{~km}$ from the primary core related to the Aryan era in the west of city, A range of $20 \mathrm{~km}$ from related to the Medieval era in the south east of city and the third zone is located $26 \mathrm{~km}$ northeast of city and is related to the Achaemenid period (Figure 2) (Behzadfar, 2005). 


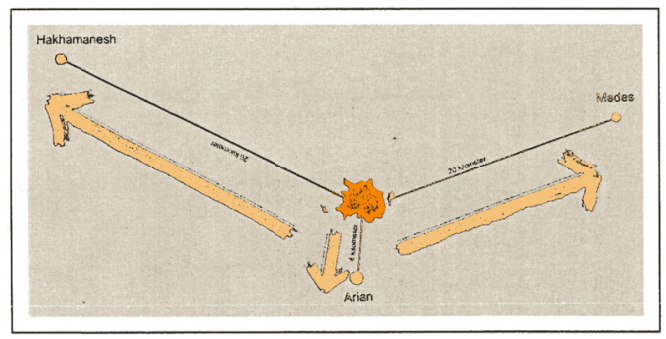

Figure 2. The primary core of city

Source: Urban Identity Studies Report

\subsection{The Development of City in Islamic Era}

Although there is no definite history for the formation of Urmia city, there is no doubt about the existence of city after Islam and according to some historical documents, it seems that this city, like other Azerbaijan cities, was conquered by Muslims at the time of Omar's caliphate. In addition, in the $6^{\mathrm{TH}}$ century, Urmia has been mentioned as a big and habitable city which was the third Azerbaijani city after Ardebil and Maragheh. At that time, Urmia was an important borderline city with a thriving business. The documents confirm the existence of strong fortresses, the tower, the rampart and city's market. There was a river in the city that spilled out of city to the lake. Thus, Urmia was largely a thriving and large city from the third to the eighth centuries, which was considered important commercially and borderline position and was occurred only a period of devastation and decline in the early $10^{\text {th }}$ century (Behzadfar, 2005) (Figure 3 ).

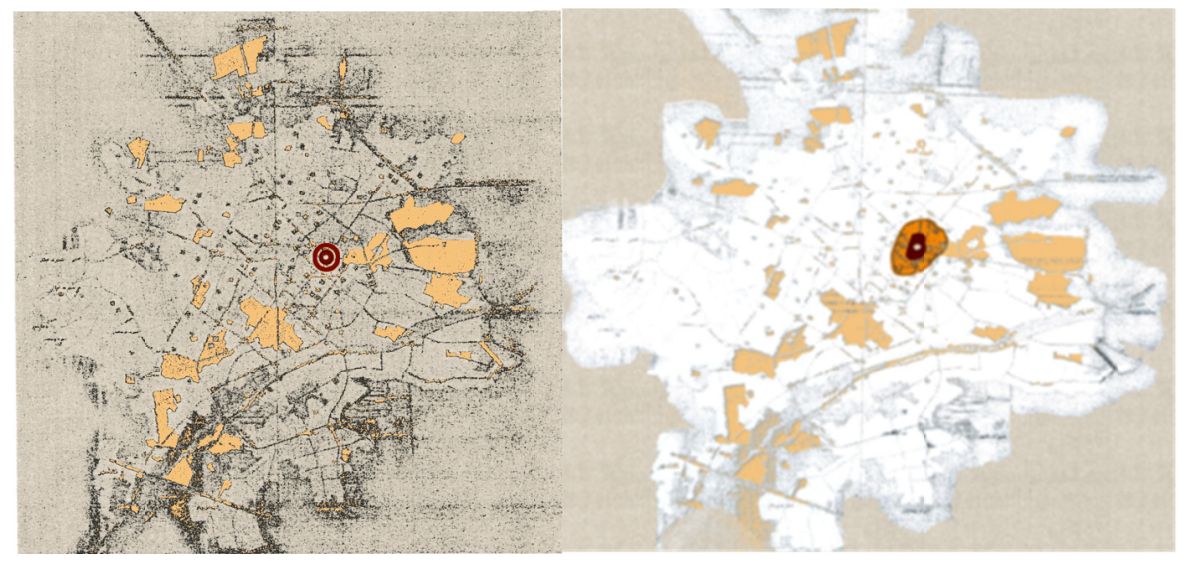

Figure 3. City form in the Sassanid era (Left) and City Form in Islamic Period (Right)

Source: Urban Identity Studies Report

\subsection{The Development of City in the Middle Ages}

Since the mid-15th century, that the Ottoman Turks replaced the Eastern Roman Empire, Urmia was still an important borderline city for the central government of Iran and it has kept its tower and rampart. In general, the position of Urmia establishment -in terms of the commercial routes of Caucasus, Minor Asia and Mesopotamia has not only provided conditions for the development of civilization and urban life, but also has created outstanding conditions for this city historically, culturally and economically.

In the Safavid period - Urmia is described as a city with 60 districts and parish with 6 thousand houses and 8 mosques and 150 villages. The people of Afshariyah and Zandieh, who dominated the city in 12th and 13th centuries (the 17th and 18th centuries), were constantly fighting with the neighboring tribes, especially the Kurds. That's why the city of Urmia, in this period despite favorable natural position, there was no major development and only a few changes occurred in the city.

\subsection{Development of City in the Qajar Period}

In the Qajar period, with slow growth and development of city, moat and outer wall of city was changed, and 
slightly expanded. At the end of Qajar period, the number of city's gates increased to 7, governor's seat also became larger, buildings such as Russian consulate, schools and hospitals were built in the city and the number of mosques was also increased. Activity of missionaries of Christianity in the region, simultaneously with the Qajar dynasty was an important event of 19th century. They also had headquarters in Urmia. In the late nineteenth and early twentieth century, the city was surrounded by a wall of 3 to 4 miles with 7 gates, which was expanded later and the number of gates was increased. In general, during this period, Urmia has always suffered from a lot of political incidents, including attacks by Russian and Ottoman government and internal religious conflicts due to borderline position and residence of different ethnic groups in its neighborhood. After the end of First World War, the devastation caused by the clashes of these governments created great damage to the city. A lot of people also died. The first map containing information about the rampart, gateways, roads and townships is related to the Qajar period, probably in the late 19th century, after the Kurdish uprising in 1880, which is a military map. It introduces the main points, gates, ramparts and roads of city. The producer of this map has been registered by an Iranian person named "Asadullah Khan", Sultan of new artillery and a foreigner named Captain Waggs (Figure 4).

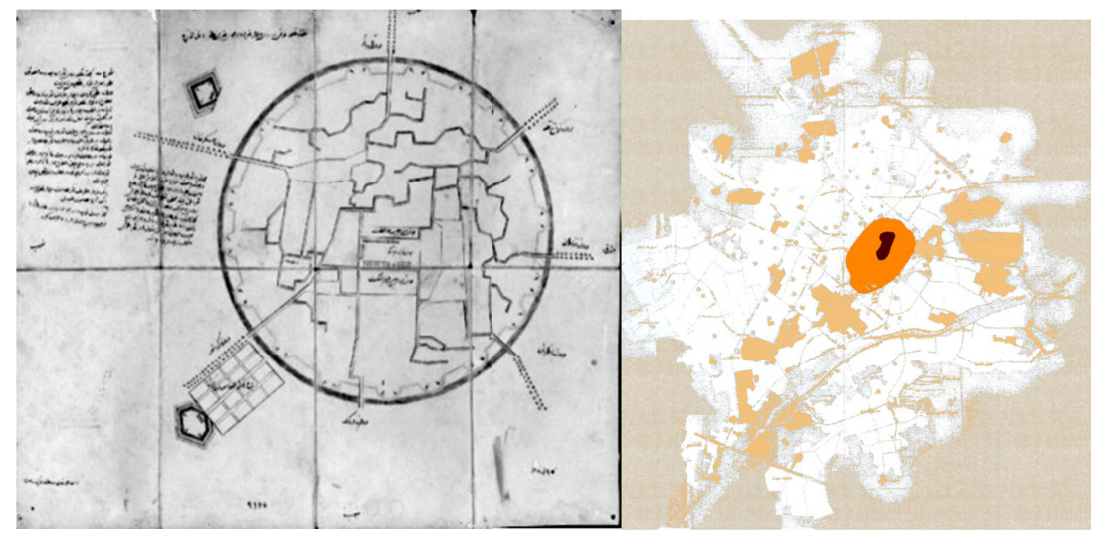

Figure 4. Map of Urmia City in late Qajar period (Source: Urmia Municipal Documentation Center) and City form in Qajar period

Source: Urban Identity Studies Report

Accordingly, Urmia to the late Qajar period and prior to the beginning of 1921 century with an area of 277 hectares with an area of about 277 hectares, was included coherent and integral complex with tower and rampart and the only way to connect this set to the outside world was the seventh gates, which were built at the right places of rampart and on the path of city communication roads. Therefore, development of ancient city texture from the beginning to the end of Qajar period can be expressed in the image below (Figure 5).

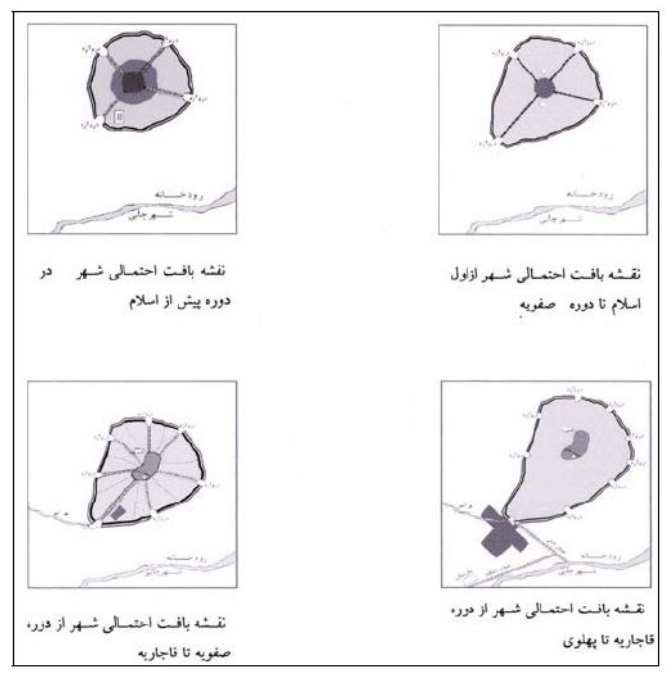

Figure 5. Development of ancient texture from the first to the end of the Qajar period

Source: Behzadfar, 2005 


\subsection{The Structural and Physical Changes of City after 1921 (Contemporary Period)}

We know that the physical development of cities is a dynamic and inevitable process in which the physical limits of city expand in different directions and cause a change in land cover situation in the region (Shams et al., 2009). In this section, we will examine the physical changes of city during the contemporary period in several time section until 2011.

\subsection{From 1921 to 1933}

Since the early years of the 1921s and the beginning of Reza Khan's rule, changes have taken place in the political structure of the country, which caused changes in the physical structure of cities. These changes, which were created with the aim of modernizing social life, especially in the cities, made fundamental changes in functional and physical traditional structure of cities. Most of the measures that took place in these era, especially from 1933, were the reopening of wide streets and the creation of modern functional spaces. Accordingly, in 1933, in order to expand the Urmia city, the tower, rampart and the gates of city were destroyed and the ditches were filled around the city. In the same year, the city was divided into four sections by two streets perpendicular to each other (Figure 6).

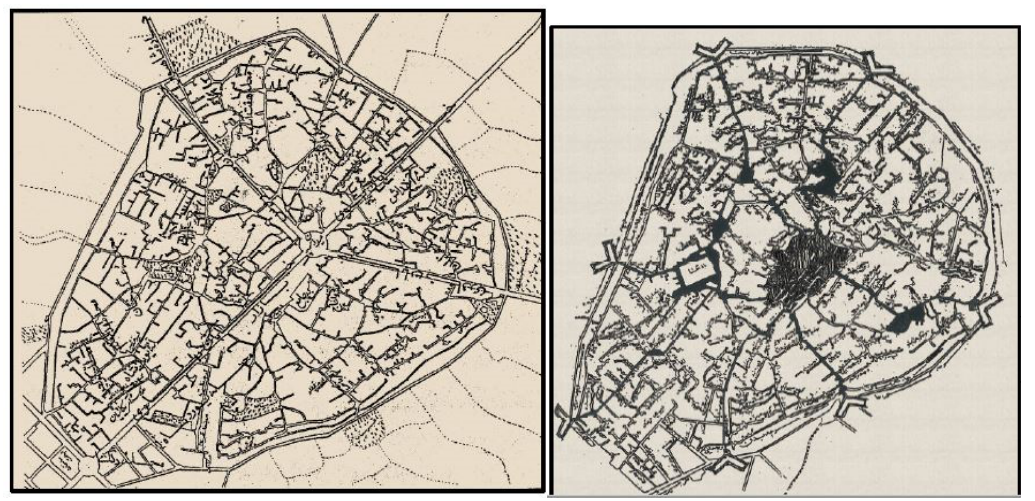

Figure 6. City after the streets of 1933 and City form at the beginning of the 1921

Source: City Identity Studies Report

The city's map before the streets of 1933 shows that until this year, the city still has preserved its traditional structure together with the tower, rampart, gates, as well as the system of formation of parishes and ancient passages. Until this year, the texture of city was dense and with a narrow-width network and screwed alleys were stretched into residential parishes. The gates of city also led to the mosque, market and parishes through these passages. Therefore, before 1933, the elements of city-forming masonry were including: 1 . walls, ditches and gates, 2. market complexes and elements inside it (baths, caravansaries, schools, etc.), 3. City's mosque that is inside the bazaar, 4. government buildings and 5. residential parishes. It is worth noting that the ancient texture range has the least extent of open space, and the gardens are mostly outside of the ancient texture (bazaar and its parishes) (revision of the comprehensive plan of Urmia city, 2010: 83).

\subsection{From 1933 to 1960}

In this period, despite the rapid interventions that had taken place in the city texture, the city was slowly growing. The most important factor affecting the spatial organization of city was the penetration of cars into the streets and transference of commercial and industrial applications to the edge of new streets. The expansion of the Urmia city during this period has been around the central core and in an immediate link to it. In the first two decades of the second Pahlavi period, the reopening of several new streets created a new ground for urban texture transformation. With the construction of Asgarabadi Street (current Be 'sat), from the southern entrance to the bazaar, passing through "Bazaar Bash" disappeared. Also, the reopening of the Bakery Street along the Pahlavi Street has led to the formation of a trapezoidal urban block that is located bazaar complexes on the its western edge. Thus, the bazaar complex was separated from the three edges of North, West and South by new streets from its surrounding tissue. In the early years of the 1951's, with the construction of Iqbal Street on the eastern edge of market, the process of isolation was completed and the bazaar was blocked from the four sides of the street. In addition, the opening of Iqbal Street, which was at least distant from the bazaar and on the eastern edge of comprehensive Mosque, cut off the main passages leading to the bazaar in the east. Finally, a part of the 
adjacent residential texture that was located on this street became a commercial axis during the 1951s (Behzadfar, 2005 and Safamansh et al., 1999).

\subsection{From 1961 to 1978}

Following the widespread changes in the livelihood condition of urban population, which resulted from the "car" penetration to city, the migration of villagers to the big cities, provincial centers, and Urmia, was began. From 1964 onwards, following the land reform in the country and its effects, the influx of immigrant populations into Urmia intensified as in other cities. These migrations were the basis for emergence of disruptive parishes such as Aliabad, Kazemabad, Shahrokhabad, as well as some marginalized villages. Urmia physical development during this period mainly done up by annexing some of the adjacent lands to city. It is noteworthy that, despite the city's expansion, not built so many open urban spaces in such spaces. In the mid-1971s, following the wake of rising oil prices and oil revenues in the country, the development of most cities, including Urmia, occurred in a jump. During this period, all parts of the city, especially north, south and southwest of Urmia, were developed. The extent of city reached to 2021 hectares during this period. In general, measures regarding the discontinuous development of city in this period, was carried out both by formal institutions and informal institutions and natural arena of city's environs was attacked. In addition, with the construction of a slaughterhouse, water organization and offices located on the Salmas Road, some residential units were formed beside of them. In this period, the city has not yet been integrated with the river and Gradually, the hierarchy of network, parishes and urban facilities was forming in Urmia. After emerging a dense texture with extensive communication networks, in immediate loop of ancient texture from 1933 to 1960, the next loop was emerged with a newer texture in which its communications network was consist of hierarchy.

\subsection{From 1978 to 1987}

Following the victory of the Islamic Revolution in 1978, and subsequently occurring imposed war, it was occurred unrests in the south and west of province. These unrests have caused the more migration of villagers and province's people of other urban areas. The extent of the city doubled over the years 1978 to 1987 (about ten years), and the number of huggermugger parishes and immigrant population housing area has grown significantly. During the years after the Islamic Revolution until 1987, some of the new axes were annexed to the city which were often used to connect of townships and cooperative structures to the city. In the texture of recent periods, which includes post-1977 construction, there are straight and vertical streets with different widths. It seems that in their formation, natural elements and other artifacts available in the city have been neglected. Bahonar, Rajai and Khatamalanbia highways, are located around the city, which their forms have partially followed by the ancient fence of city. Also, until the late 60 's, the overall bazaar condition remained affected by changes in the 30 's. But at this time, due to the destructions caused by imposed war, destroyed part of the residential texture in east of Iqbal Street and turned into the open space form.

\subsection{From 1987 to 1996}

During this period, the population growth with a slower pace than a decade ago but the increasing extent of city and its physical development was continued to be remarkably intense. In this decade following the end of imposed war and creation of security and relative stability in country has diminished the process of migration and consequently the development of huggermugger settlements has decreased. The area of city reached about 7,000 hectares in 1996, this means that within 20 years the area of city has increased five times. During this period, the number of settlements also was appeared inside the city.

\subsection{From 1996 to 2006}

In the last few years, the area of city has reached about 7,200 hectares, and the annexation of new lands in the city is prevented. The city's physical development has been further occurred through the interior construction of region and its surrounding villages. In these years, the policy of increasing buildings congestion and vertical development has been on the agenda. In addition, measures have been taken by a number of housing cooperation's outside the legal area of the city, that construction has often not been done in them. Meanwhile, due to the excessive migrations in recent decades and the dispersion of new texture, the form of city has somewhat become heterogeneous and the town construction of state organs also reduce the city's integrity.

\section{Physical Development and Process of City's Historical Formation}

From the study of physical development features and process of Urmia city's historical formation in different periods, the following are deduced:

1) The ancient area of Urmia city, with an area of nearly 300 hectares before the beginning of $1921 \mathrm{~s}$, was a coherent and integrated totality which was defined by peripheral rampart and the only ways to connect with the 
outside, was septet gates of city. This totality and its functional and physical structure had identical and unalterable characteristics until 1921, during different periods.

2) The establishment of Urmia on important commercial routes, also the borderline situation, favorable climate conditions and natural resources have always provided the possibility for development of civilization and prosperity of urban life in it and the only deterrent factor to the development of city, in the centuries before 1921, was the attacks of neighboring countries and religious and ethnic conflicts in the city.

3) Until the late reign Qajar dynasty in Iran, the Urmia city has grown slowly and mostly had agricultural relations. But since 1921 with the involvement of Reza Khan in the cities, the city has undergone fundamental changes in its structure and function. From this time onwards, due to physical development, immigration to the city intensified, its changes became faster.

4) The main factor influencing the city's development, in the last century before 1978, was layout of streets, creation of modern physical and functional space in cities, as well as land reform and the phenomenon of immigration. But after the victory of Islamic Revolution, due to the presence of insecurity in cities, especially borderline's cities and villages in the south and west of the country (due to the occurrence of imposed war), migration to cities such as Urmia was intensified, and its effect became more pronounced than other factors. So that almost half of the migrant population to Urmia, in the decade leading up to 1986, was entered in the city.

5) In the last two decades, the main factors in the physical development of city have been the development of roads and housebuilding around them and to a lesser extent, the phenomenon of migration. that has led to the annexation of peripheral lands to city, cooperative town construction, development and creation of huggermugger habitations and marginalized settlements.

6) In recent years, the policy of increasing congestion, especially through vertical development, has been on the agenda, in order to respond to the problems caused by city's horizontal development, increasing population and need for housing.

7) The lack of residential units' establishment in isolated areas, especially in the lands of government cooperatives and organs shows that these measures have not been in the real needs of city, and the economic issues of land and housing have been affected in this.

After generating axial maps, the spatial variables of city and historical texture range are calculated in four periods, graphically and mathematically, and each of them is analyzed separately and then compared with each other. To analyze urban morphology, the Space Syntax provides a spectrum of spatial characteristics. The variables studied in this research include the criteria and elements of studying the spatial structure of city, parameters of spatial organization in city and historical range of city, which was cited in the theory of space organization (both enormous and local link- medium depth of enormous- control- connection).

Summing up these materials, the urban structure can be considered as city's composition and skeleton and all the factors that create a city and the structure of a city is the common concept of system, pattern, hierarchical relationship, communication networks, spatial organization, and combination of its various factors.

As stated in the theoretical framework, the structure of city is the same constant and enduring elements of city that constitute the main skeleton of city. One of the most important elements of the study of city's space structure is the passageways and axes of city, that form the backbone of city. Of the other elements, we can point to criteria with a functional scale and a large functional importance, such as markets, mosques, squares and public urban spaces which have a spatial-physical value and act to identify the region and whole of city and they are main elements linking the city and historical ranges. In the tables and diagrams below, the general framework of research, and the criteria and variables used for analyzing, from whole to part are illustrated, graphically and tabular. As seen in the Figure 7, we sum up the criteria for studying and analyzing the structure of city space in three standards which includes the lands use pattern, value and importance of the main elements and components of city's structure and the spatial dispersion and coherence of city's structure. The first standard is to examine the distribution of activities within their range and congestion. The second standard analyzes the value and importance of historical axes of area, public urban spaces and major activity centers during the time periods specified and finally, the third standard considers and analyzes the integrity and fragmentation of the city's spatial structure and the boundary. 


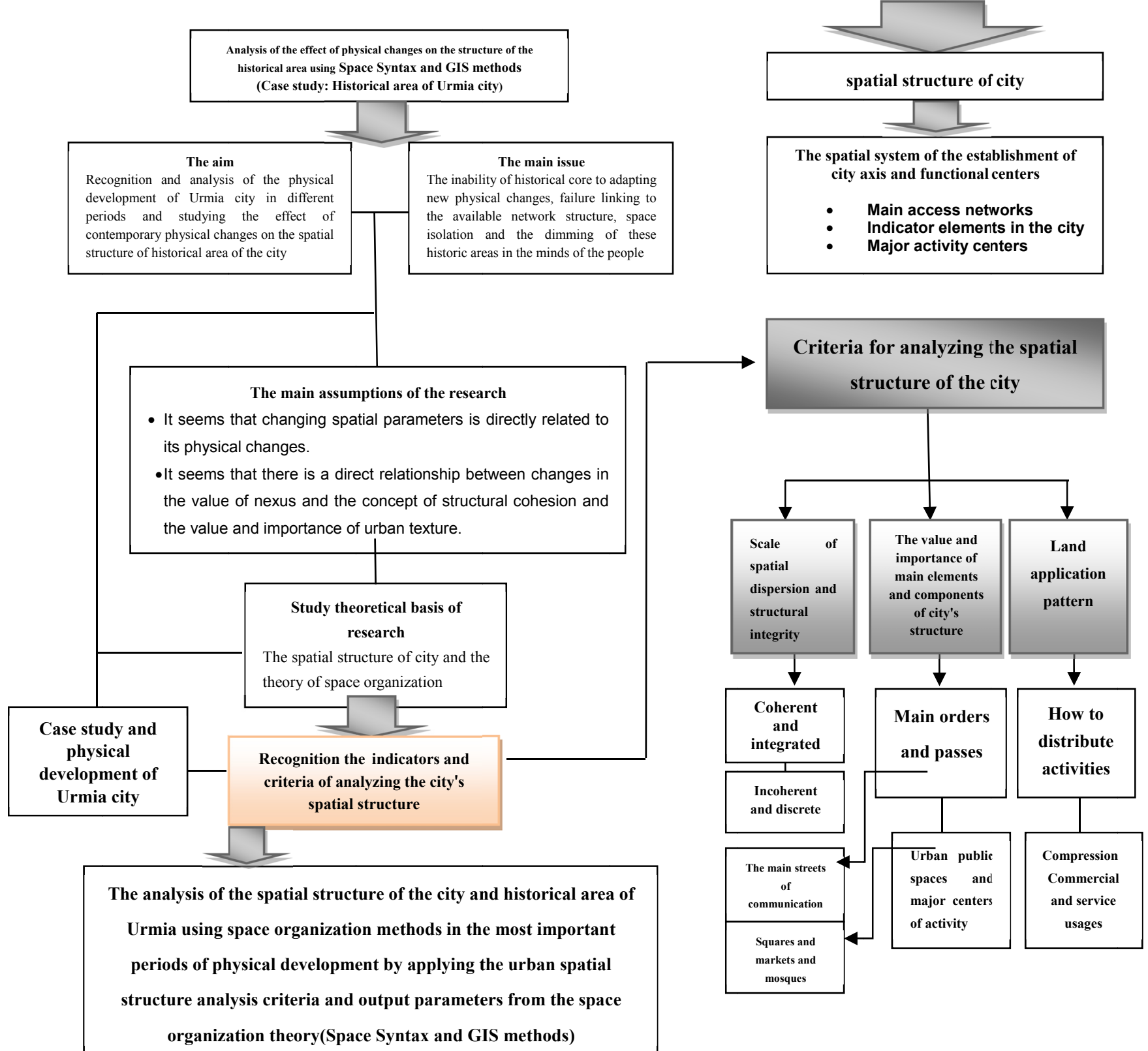

Figure 7. General framework for research and criteria 
Table 4. Criteria and sub-criteria of spatial structure analysis of the city and its relationship with spatial variable parameters

\begin{tabular}{|c|c|c|c|c|c|}
\hline Description & $\begin{array}{c}\text { Spatial Variable } \\
\text { Parameters } \\
\end{array}$ & Topics Reviewed & Sub metrics & Metrics & \\
\hline $\begin{array}{l}\text { The greater the degree of } \\
\text { spatial integration, the } \\
\text { greater the coherence and } \\
\text { coordination of the spatial } \\
\text { structure. } \\
\text { The greater the degree of } \\
\text { deviation in the } \\
\text { interconnectedness value, } \\
\text { the greater the coherence } \\
\text { and integrity, and the } \\
\text { spatial fracture is less. }\end{array}$ & Standard deviation & $\begin{array}{l}\text { Investigate the } \\
\text { performance and } \\
\text { integrity of the whole } \\
\text { city }\end{array}$ & \multirow{2}{*}{$\begin{array}{l}\text { Coherent and } \\
\text { integrated } \\
\text { Or } \\
\text { Incoherent } \\
\text { and discrete }\end{array}$} & \multirow{2}{*}{$\begin{array}{l}\text { Spatial } \\
\text { Dispersion } \\
\text { and } \\
\text { Coherence } \\
\text { of the } \\
\text { Historical } \\
\text { Range } \\
\text { Structures }\end{array}$} & \\
\hline $\begin{array}{l}\text { The greater the difference } \\
\text { between the average of the } \\
\text { historical range of the mean } \\
\text { of the total } \\
\text { interconnectedness, the } \\
\text { internal structure of the } \\
\text { range is discrete and has an } \\
\text { inappropriate connection } \\
\text { with the city. }\end{array}$ & $\begin{array}{l}\text { Comparing average } \\
\text { of the historical } \\
\text { range } \\
\text { interconnectedness } \\
\text { and } \\
\text { the average of } \\
\text { whole city } \\
\text { interconnectedness }\end{array}$ & $\begin{array}{l}\text { Investigate the } \\
\text { performance and } \\
\text { coherence of the } \\
\text { historical range } \\
\text { relative to the city }\end{array}$ & & & \\
\hline $\begin{array}{l}\text { The higher the value of } \\
\text { axis interconnectedness } \\
\text { than the average total } \\
\text { interconnectedness value, } \\
\text { the higher its structural } \\
\text { significance than the } \\
\text { average structural } \\
\text { significance of the whole } \\
\text { city } \\
\text { The closer the value of axis } \\
\text { linkage to the average of a } \\
\text { city closer to or lower, it } \\
\text { shows a lack of } \\
\text { differentiation or even a } \\
\text { lower structural value of } \\
\text { that axis than the whole. }\end{array}$ & $\begin{array}{l}\text { Comparison of the } \\
\text { average value of } \\
\text { each axis's } \\
\text { interconnectedness } \\
\text { to the average value } \\
\text { of the whole city's } \\
\text { interconnectedness }\end{array}$ & $\begin{array}{c}\text { Reviewing and } \\
\text { comparing the value } \\
\text { and importance of } \\
\text { axis structural relative } \\
\text { to the whole city } \\
\text { structure }\end{array}$ & $\begin{array}{c}\text { Main orders } \\
\text { and } \\
\text { passages }\end{array}$ & \multirow[t]{2}{*}{$\begin{array}{l}\text { The value } \\
\text { and } \\
\text { importance } \\
\text { of the main } \\
\text { elements } \\
\text { and } \\
\text { components } \\
\text { of the } \\
\text { historical } \\
\text { range } \\
\text { structure }\end{array}$} & $\begin{array}{c}\text { Criteria for } \\
\text { analyzing the } \\
\text { spatial structure of } \\
\text { the city }\end{array}$ \\
\hline $\begin{array}{l}\text { By comparing the values of } \\
\text { aggregation and depth, over } \\
\text { time, the value of spaces } \\
\text { and their position in the } \\
\text { structure of the tissue is } \\
\text { determined. }\end{array}$ & $\begin{array}{c}\text { Comparison of } \\
\text { spatial parameters }\end{array}$ & $\begin{array}{c}\text { Comparison of the } \\
\text { average value of each } \\
\text { axis's } \\
\text { interconnectedness to } \\
\text { the average value of } \\
\text { the whole city's } \\
\text { interconnectedness }\end{array}$ & $\begin{array}{l}\text { Public spaces } \\
\text { and major } \\
\text { centers of } \\
\text { activity }\end{array}$ & & \\
\hline $\begin{array}{l}\text { Explaining and reviewing } \\
\text { the relationship between } \\
\text { the degree of } \\
\text { interconnectedness of axes } \\
\text { and the distribution of } \\
\text { business and service } \\
\text { activities (travel attraction) } \\
\text { per year }\end{array}$ & $\begin{array}{c}\text { Adaptation } \\
\text { interconnectedness } \\
\text { map on the map of } \\
\text { service-commercial } \\
\text { users each year }\end{array}$ & $\begin{array}{l}\text { Investigate the } \\
\text { relationship between } \\
\text { catchy and important } \\
\text { users and city's } \\
\text { activity centers with } \\
\text { important orders }\end{array}$ & $\begin{array}{c}\text { How to } \\
\text { distribute the } \\
\text { user }\end{array}$ & $\begin{array}{l}\text { Land use } \\
\text { pattern }\end{array}$ & \\
\hline
\end{tabular}




\section{Conclusion}

This project has been dealt with aims to examine the impact of contemporary urban development projects and physical changes on historical structure of Urmia city and analysis of urban spatial structure and historical city boundary in four important periods of developments with the space layout method which is a new approach and methodical to spatial analysis and configuration. In this section of paper, we present a general conclusion according to analysis of each section. First, the general result of analysis of spatial parameters of Urmia metropolitan structure in the four selected periods, and second were the general conclusion of the analysis of the relationship between changes in the structure of selected indicators to investigate the spatial structure of city and historical boundaries (coherence and distribution of city structure-value and importance of the main elements of the city-distribution pattern) and spatial layout variables. Finally, it will have discussed about the effect of physical changes of the contemporary era on the spatial structure of a certain historical range. Analysis done in this section shows that since 1312 to now, by applying changes in the city, the metropolitan structure has also undergone major changes. So that the parameters of spatial arrangement as structural analytic variables and city configuration have changed. The moderate mean values of these four parameters, namely, interconnection, depth, connectivity and control are presented in Figure 8. The spatial interconnection as the main parameter has been reduced over time because of spatial expansion. As shown in the Figure 8 this parameter has the highest value in 1312 , that shows all spaces in this period have been combined, and there is no space was separated from the structure of city. And every space of the public and private spaces has its own functional place. Imam street and historical bazar were the main elements of the city's architecture at the top of these communications and the whole city has been well integrated. With expansion of city, the spatial interconnection has reduced, and city developed out of balance. Red line in figure 8 also shows that distance among space increase over time. Spatial utility has slowly diminished from 1312 to 1395 , and the main structure of the city has been affected. While city experienced unorganized development, city integration reduced.

Also, the difference between minimum and maximum amount of depth in the city from 1312 to 1395 is significant, that shown in Figure 9. The expansion of the city was out of balance and structural system and as separated parts. Development of street in 2016 does not contribute to spatial interconnection of spatial elements. Still, there is no appropriate accessibility because of the neglected aboriginal spatial structure.

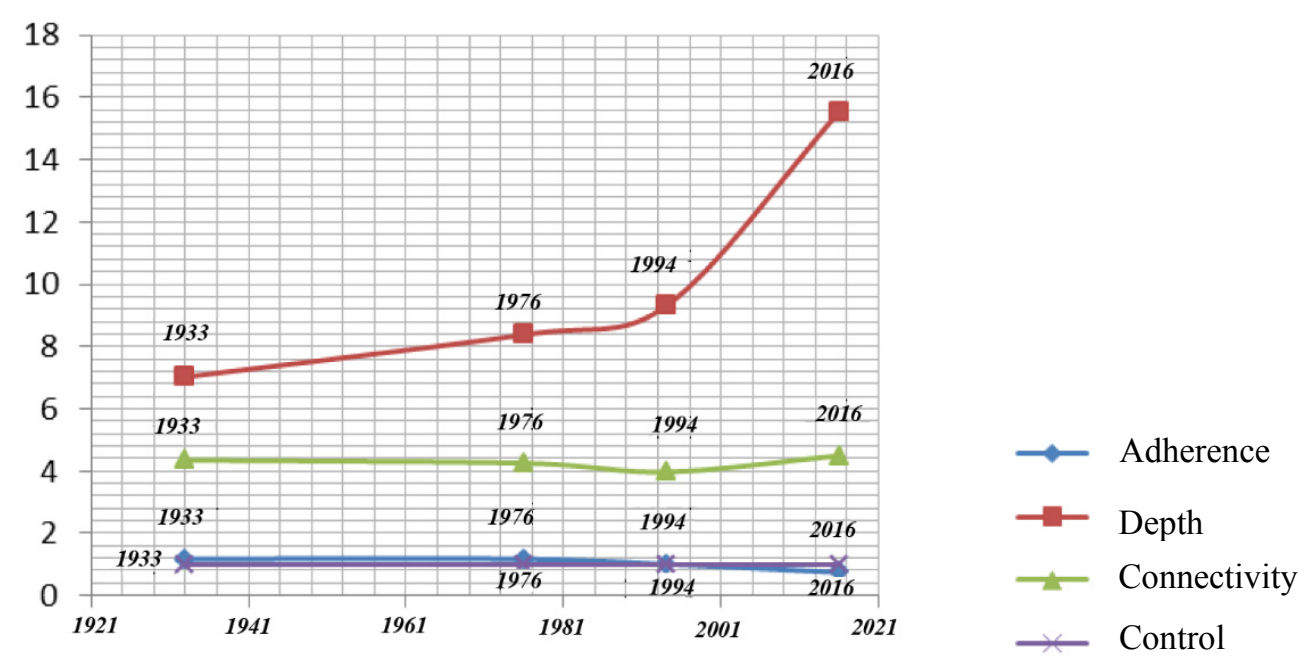

Figure 8. Spatial Parameters of Metropolitan Structure in Four Periods (Space Syntax) 


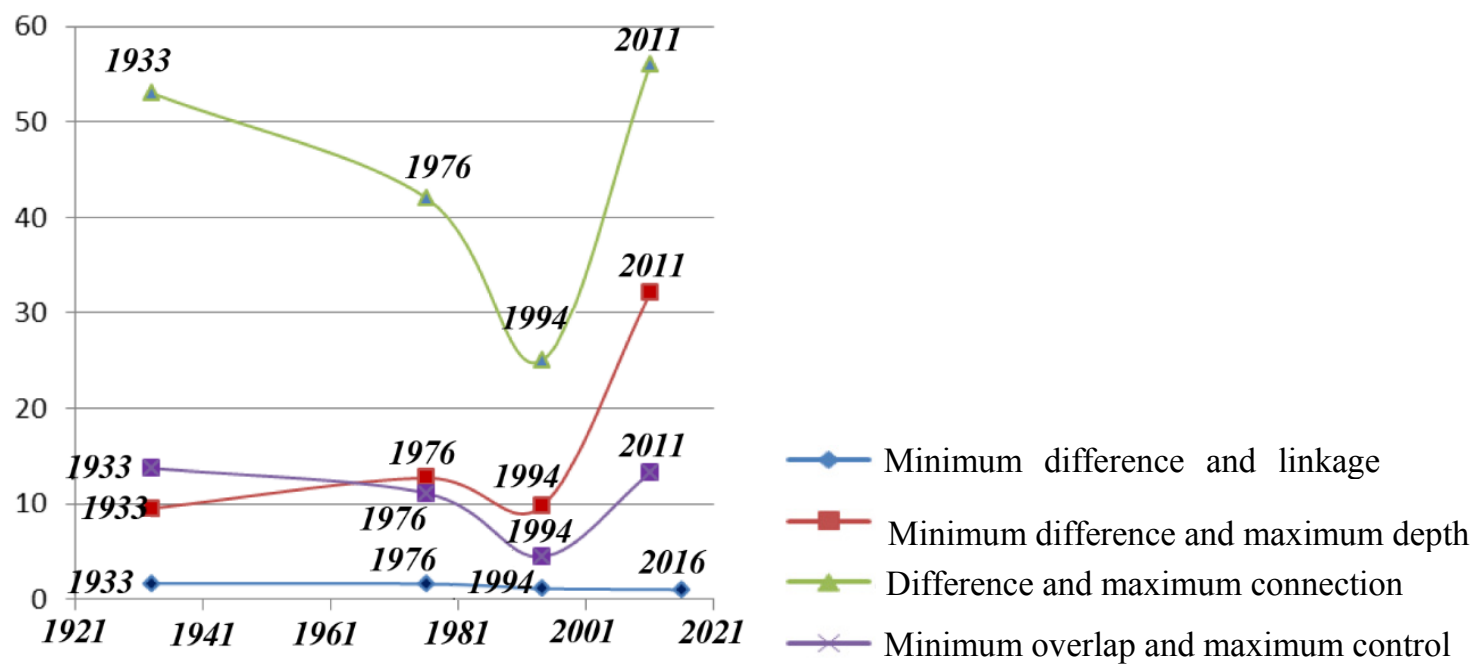

Figure 9. Comparison Difference between the Smallest and Highest Spatial Parameters (Space Syntax)

\section{References}

Ahmadifar, A. (2006). The city as one thing. Progress in Planning, 67(3), 27.

Ambinakudige, S., Parisi, D., Cappello, G.C., Lotfata, A. (2017), Diversity or Segregation? A Multi-decadal Spatial Analysis of Demographics of Atlanta Neighborhoods. Spatial Demography, 5, 123. https://doi.org/10.1007/s40980-017-0034-z

Bahraini, H. (2009). Contemporary Urban Design. Tehran University Press.

Bazrgar, M. (2003). Urban planning and construction. Koushemare Publication, Shiraz.

Behzadfar, M. (2005). Report of studies in search of Urmia urban identity. Ministry of Housing and Urban Development of the National Land and Housing Organization, Tehran.

Dolati, R. (2013). Investigating the Impact of ICT on the Disturbance of Space and Urban Structure, Case Study of Kerman. Urban Planning Studies, 3, 121-99.

Ganbari, M. A. (2008). Structure, Structuralism. Journal of Iran Sociology, (3).

Harvey, D. (2000). Social Justice and the City. Translator: Farrokh Hesamian et al. Urban Processing and Planning (Affiliated to Tehran Municipality).

Hillier, B. (2007). Space is the machine. Press Syndicate of the University of Cambridge.

Lefebvre, H. (1991). The production of Space. Wiley-Blackwell.

Lotfata, A. (2008). Effect of Environmental Factors on Behaviors and Learning, in Educational Spaces (Especially Elementary Schools). Modiriyat Shahri - No. 21. Retrieved from http://www.magiran.com/view.asp?Type=pdf\&ID=751998\&l=en

Lotfata, Y. Lotfata, A (2018). Resiliency of Open Public Space (Streets) through Transferring Memory "Graffiti and Wall Arts in the Tehran Streets", International Journal of History and Scientific Studies Research (IJHSSR), 2(2)

Lotfata, A. (2013). Epistemological Differences in Tactical and Strategic Spatial Planning. Global Journal of Computer Science and Technology Neural \& Artificial Intelligence, 13(1). Retrieved from https://globaljournals.org/GJCST_Volume13/1-Epistemological-Differences-in-Tactical.pdf

Lotfata, A. (2013). Transformation of Urban Spaces through Time-Space Politics towards Ethical Developing Urban Spaces in Turkey Context. Global Journal of Human Social Science Political Science, 13(4).

Lotfata, A. (2015). Urban Diversity in the Middle East: A Case Study of Tehran. International Journal of Culture and History, 2(1). https://doi.org/10.5296/ijch.v2i1.7887

Lotfata, A., \& Sadeghi, M. J. (2009). The Creative City, Reflecting New Planning Tendencies for Cities, $5^{\text {th }}$ 
Symposium on Advances in Science and Technology, Mashhad, Iran.

Madanipour, A. (1996). Design of Urban Space. John Wiley \& Sons, New York.

Pakdaman, B. (1993). Tips on Designing New World Cities. Abadi Magazine, (8), 41-33.

Pakzad, C. (2006). Theoretical Basis and Urban Design Process. Tehran Technical \& Engineering Organization, Shahidi Publishing House.

Rismanchian, A. (2010). A Methodic Approach to Pedestrian Moving Management, Case Study: Tehran. Parallel Magazine, (8), 39-36.

Rismanchian, A., Pourdihimi, S., \& Observatory, M. (2013). The Relationship between Cognitive Characteristics and Space Configuration of the Artificial Environment, an Experiment in Dezful. Iranian Architectural Studies, Two Iranian Journal of Architecture, (4), 64-37.

Sadeghi, S., Qala Nawi, M., \& Mokhtarzadeh, P. (2013). The Impact of Contemporary Urban Development Projects on the Spacecraft Structure of the Historical Core of the North of the City of Isfahan. Journal of Urban Studies, 3(5), 12-3.

Safamanesh et al. (1999). Urban design in part of the historical texture of Urmia city. Department of Housing and Urban Development. Tehran.

Shams, M., \& Haji Malayeri, P. (2009). Physical Development and its Impact on Land Use Changes in the City. Geographical and Environmental Planning: 23, Malayer Azad University Press, pp. 92-75.

Sharmand Consulting Engineers. (2006). Plan the location of residential buildings of four floors and more in Urmia. Housing and Urban Development Organization of West Azarbaijan province. Urmia.

Simmel, G. (1993). Metropolis and Mental Life. Translator: Yousef Abazari, Social Sciences Quarterly, No. 3. Second Volume. Tehran University, pp. 65-54.

Weber, M. (1990). The city over time. Translator: Shiva Kaviani. Publications joint-stock Co. Tehran.

Zekavat, F. (2011). Identifying the factors affecting the urban dispersion and its relation with the spatial structure of the city studied: Urmia. Architectural and Urban Design Letter, Journal of the University of Art, (7), 117.

Ziari. (2013). Metropolis and Mental Life. Translation by Yousef Abazari, Journal of Social Sciences, No. 3, Tehran University, p. 36.

\section{Copyrights}

Copyright for this article is retained by the author(s), with first publication rights granted to the journal.

This is an open-access article distributed under the terms and conditions of the Creative Commons Attribution license (http://creativecommons.org/licenses/by/4.0/). 